\title{
Presença da Identidade Eleática na Filosofia Grega Clássica
}

José Trindade Santos (UFPb)

This paper argues for two highly debatable readings of the argument in Parmenides' "Way of Truth": (1) "Is" (B2.3) does not refer to the physical world; and (2) to auto (B3; B8.34) establishes the identity of knowledge and the known. A standard interpretation of the "Way of Truth" leads to an appraisal of the influence of its main tenets on the Greek cosmologists, the sophists and Plato. I aim at suggesting that "thinking" less than a faculty should be seen as an epistemic perfect state; and "being" as the unity of what can be thought of, of which Aristotle's "productive thought" would be a late echo.

A atenção concedida ao Poema de Parmênides e ao estudo da influência que exerceu no pensamento grego subsequente, bem como, através das obras de Platão e Aristóteles, na tradição filosófica ocidental, tem sido constante nos últimos anos. Embora seja notável a tendência recente para concentrar esforços na reabilitação da chamada Via da Opinião, persistem, no seio das áreas de consenso que agrupam os intérpretes, diferendos não resolvidos, focados na Via da Verdade.

Começarei por esboçar uma breve resenha de alguns dos problemas que os justificam, para passar depois à avaliação da relação entre pensamento e ser, bem como aos sinais da sua presença noutros pensadores da tradição, nomeadamente em Platão e Aristóteles. Irei concentrar-me nos fragmentos 3 e 8.34 do Poema:

"o mesmo (to auto) é pensar (noein) e ser (einai)";

"o mesmo é pensar e [aquilo] de que há pensamento".

\section{A mensagem do Poema}

1. B2-B3: os dois caminhos 
Journal of Ancient Philosophy Vol. III 2009 Issue 2

O proémio do Poema é rematado pelo início do discurso que a deusa dirige ao jovem referindo as temáticas paralelas que a sua lição irá contemplar: a "verdade/realidade" (alêtheiê) e as "crenças dos mortais". Sem que se torne manifesta uma ruptura com essa declaração, B2 marca o início do argumento da deusa.

O fragmento começa por apontar os "dois únicos caminhos que podem ser pensados": "é" e "não é". Não prestando atenção ao debate sobre o sentido da tradução potencial de einai em B2.2, aceita hoje pela maioria dos intérpretes, concentro-me no problema posto pela ausência de sujeito gramatical nas duas proposições.

Parece indisputável que a deusa não quis, ou não achou necessário, informar o jovem e os eventuais destinatários do relato que este irá fazer do sujeito das duas cláusulas paralelas ${ }^{1}$. Creio ser preferível encarar esta ausência de sujeito gramatical como uma decisão deliberada a considerá-la uma falta; como se a deusa quisesse dissociar a afirmação - "é” - dos seus eventuais sujeito e complemento.

Não será necessário imaginar um ou dois sujeitos - um, do que é; outro, do que não é -, para que as proposições tenham sentido ${ }^{2}$. É admissível que a deusa recorra à metáfora dos caminhos para sustentar tese de que toda investigação (dizêsis) recorre aos dois únicos pensamentos possíveis: "é” e "não é”.

\footnotetext{
${ }^{1}$ Note-se que a presença explícita de um sujeito não é requerida em todas as línguas do mesmo modo. É patente, em inglês, francês ou alemão, por exemplo, a necessidade de introduzir um pronome que represente o sujeito indeterminado: "it", "il", "es". Pelo contrário, em português, espanhol ou italiano, não só "é" e "não é" podem ser expressos de forma gramaticalmente correta sem sujeito, como não se sente de modo premente a necessidade de imaginar sujeitos para os dois caminhos.

${ }^{2}$ Este pressuposto é preservado por algumas respostas ao problema: por exemplo, E. Hussey, The Presocratics, London, 1972, 82, ou G. Owen, "Eleatic Questions", Studies in Presocratic Philosophy (OSAPh), R. E. Allen, D. J. Furley (eds.), London 1975, 60, n. 49. Outras propostas concentram-se nas proposições e no seu conteúdo: Aryeh Finkelberg, "Parmenides' Foundation of the Way of Truth", Oxford Studies in Ancient Philosophy VI, Oxford 1988, 45: "a única solução gramatical possível é encarar o estin como se implicasse o seu sujeito próprio"; vide G. Calogero, "Parmenide", in Studi sull'eleatismo, Firenze 1977 (1ª ed. 1932), 7: "Este ser não é outro que o ser do juízo: o é da afirmação"; para apoio da interpretação aqui apresentada, vide Op. Cit. 22 ss. Para o enquadramento desta posição, vide A. P. D. Mourelatos, The Route of Parmenides, New Haven \& London 1970, 51-61. Vide ainda Mitchel Miller, "Ambiguity and Transport: Reflections on the Proem to Parmenides' Proem", Oxford Studies in Ancient Philosophy XXX, 2006, 1-48. Chamo a atenção para o fato de a interpretação do Da natureza aqui apresentada ser devedora das leituras que G. Calogero, A. P. D. Mourelatos e C. H. Kahn (vide infra n. 4) - os dois últimos em diversos estudos -, propõem do Poema de Parmênides.
} 
Journal of Ancient Philosophy Vol. III 2009 Issue 2

Todavia, a ausência de um sujeito expresso não impede que a qualquer dos caminhos se atribua um referente. $\mathrm{Na}$ verdade, essa possibilidade começa por ser sugerida na conclusão do fragmento, pois, em 2.7, “o que não é” (to mê eon) é mencionado como o que não é possível conhecer e apontar. Ora, que sentido haveria em avançar este comentário, logo a seguir à enunciação do caminho "não é", se "o que não é" não pudesse ser entendido como a designação da entidade à qual é atribuído o predicado "não é" (e, por analogia, "o que é" - to eon - como referente de "é" ${ }^{3}$ )?

\subsection{Leituras de "é" e "não é"}

A possibilidade de interpretar "não é" e "é" como predicados e suportes de predicados dá origem ao novo problema de saber que sentido pode ser conferido às traduções das formas do verbo grego einai. Este é um problema clássico da interpretação do Poema.

Entre as várias leituras atribuídas ao verbo grego 'ser', a literatura grega de que temos conhecimento permite-nos isolar quatro - a predicativa, que admite as versões identitativa e veritativa, e a existencial -, mas não é possível separar umas das outras na tradução. Perante a impossibilidade de fixar aquelas que definitivamente recolham o consenso da crítica, é aceitável propor dois princípios interpretativos, reconhecendo:

- a unidade semântica do verbo grego;

- a ambiguidade das leituras que congrega.

Este critério mínimo é bastante para superar a dificuldade de interpretação das proposições em que o verbo figura. A estratégia apoia-se na tese de Charles Kahn: “o uso da cópula é implicitamente existencial, e muitos, se não todos os usos existenciais

\footnotetext{
${ }^{3}$ Esta decisão será confirmada em B6.1a pela ligação de to eon a emmenai: vide D. O’Brien, "Introduction à la lecture de Parménide: les deux voies de l'être et du non-être", Études sur Parménide, P. Aubenque (dir.), Paris 1987, 183. Distingo "referente" de "sujeito gramatical" pelo fato de as expressões apontadas não se referirem a algo que "é" ou "não é", mas serem entendidas como nomes das classes que incluem todos os casos em que os predicados "é" e "não é" são usados. De acordo com a concepção apresentada a seguir, defendo que, como único pensamento viável, a afirmação - "é" - contém o seu próprio sujeito, sendo essa a razão pela qual suporta apenas predicados monádicos (vide S. Austin, Parmenides. Being, Bounds, and Logic, New Haven and London 1986, 33, 37).
} 
Journal of Ancient Philosophy Vol. III 2009 Issue 2

são potencialmente predicativos"4. Penso que a primeira lição a extrair desta encomendação de leitura irá no sentido da preservação da unidade semântica e da ambiguidade do verbo grego, patentes na coexistência das suas possíveis leituras ${ }^{5}$.

Do exposto, retiro duas consequências. A estratégia implica optar pelas traduções "é”, "ser” (ou “o que é"), por consentirem a possibilidade de agregar nas línguas modernas a variedade de leituras do verbo, sem expressamente rejeitar o sentido existencial. Mas a inversa não se verifica, pois o recurso à tradução "existir" desfaria a ambiguidade do verbo grego, cancelando as outras leituras que com ela potencialmente convivem.

Sintetizando, é possível sumariar algumas conclusões:

- "é” e "não é" exprimem as duas únicas opções possíveis do pensamento;

- “o que não é" e "o que é” são os nomes das entidades que congregam os predicados e suportes de predicados indicados por cada um dos caminhos;

- em “é” e "não é”, a proeminência da leitura veritativa respeita a unidade semântica do verbo grego einai, bem como a ambiguidade expressa pela "fusão" das suas diversas leituras ${ }^{6}$.

\footnotetext{
${ }^{4}$ Charles Kahn, The Verb "BE" in Ancient Greek, "Introduction", Indianapolis 2003, IX. De Kahn recolho também a defesa da leitura veritativa de einai, "The Greek Verb 'To Be' and the Concept of Being", Foundations of Language 2, 1966, 245-265 (vide "O Verbo Grego "Ser" e o Conceito de Ser", Sobre o Verbo grego Ser e o Conceito de Ser”, M. Iglésias, I. B. Franco (orgs.), Rio de Janeiro (s. d.), 1-32). Em relação a Parmênides e Platão, a teoria do autor sobre o verbo 'ser' acha-se em "Ser em Parmênides e Platão", in Sobre o verbo..., 197-227.

${ }^{5}$ A questão da unidade e ambiguidade de einai tem, desde a publicação "L. Brown, "Being in the Sophist: A Syntactical Enquiry", Plato I, G. Fine (ed.), Oxford 1999 (OSAPh IV, 1986), 455-478, continuado a receber atenção dos intérpretes, vide: L. Brown, "The Verb 'To Be' in Greek Philosophy": Some Remarks", in S. Everson (ed.), Language, Cambridge 1994, 212-236; J. Malcolm, "Some Cautionary Remarks on the "Is/Teaches" Analogy", OSAPh XXXI 2006, 281-296; F. Leigh, "The Copula and Semantic Continuity in Plato's Sophist", OSAPh XXXIV 2008, 105-122. Contra a relevância da ambiguidade na tradução de einai acha-se J. Solana Dueso, De Logos a Physis, Estudio sobre el Poema de Parmenides, Zaragoza 2006, 58-60. Apoiado em W. e M. Kneale, El desarollo de la lógica, Madrid 1980, 56, 58, o Autor confere ao esti de Parménides exclusivamente o sentido existencial: "se expressamos uma proposição verdadeira, tem de haver algo a que a proposição se refira", ... " quando pensamos ou falamos, necessariamente pensamos ou falamos de algo existente, enquanto do não existente não é possível falar nem pensar" (58).

6 A metáfora da "fusão" foi cunhada por M. Furth, "Elements of Eleatic Ontology", The Presocratics, 241-270, e condenada por J. Barnes, The Presocratic Philosophers I, London, Henley and Boston, 1979, 160.
} 
Journal of Ancient Philosophy Vol. III 2009 Issue 2

\subsubsection{A natureza de "“"o" que é”}

Associado ao problema das leituras do verbo grego 'ser' surge um outro relacionado com a natureza das entidades referidas pelos pensamentos "é" e "não é". Segundo a interpretação clássica, que remonta ao Parménides e ao Sofista platónicos, “o que é”, "o ser”, ou "o que não é”, “o não ser" são nomes atribuídos à totalidade das coisas (ta panta), ao "uno" (to hen), ou a "nada" (Sof. 237e, 238c, 244d passim).

De acordo com esta interpretação, os dois caminhos - "é" e "não é" constituem duas unidades globalmente contrapostas: "ser" e "não-ser", resolvendo-se em "o tudo" ("todas as coisas": to pan) e "nada" (mêden). Contudo, apesar de, ao longo da Via da Verdade, particularmente no fragmento 8, a contraposição das duas unidades ser constantemente reafirmada, é também possível sustentar que "o que é” poderá não ser uma totalidade, no sentido de um "tudo" (pan), mas a atomização de cada unidade constituída como um "todo" (holon); ou seja, cada uma das coisas que é pensada e é.

A questão aponta ao tipo de monismo classicamente atribuído a Parmênides ${ }^{7}$. Contra as variedades habituais - monismo numérico, ontológico ou epistemológico levanta-se a possibilidade de uma leitura mais fraca: por exemplo, um "monismo

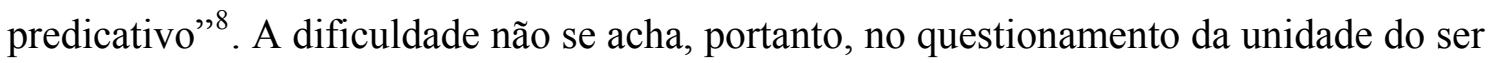
eleático, mas, como no caso anterior, na determinação do tipo de unidade que lhe deve ser atribuída.

Aceitando a sugestão de Patricia Curd, no contexto da leitura platônica dos dois caminhos, a interpretação aqui proposta vai no sentido de não conferir à unidade do ser

\footnotetext{
${ }^{7}$ D. H. Graham, "Empedocles and Anaxagoras: Responses to Parmenides", The Cambridge Companion to Early Greek Philosophy, A. A. Long (ed.), Cambridge 1999, 166, exprime dúvidas acerca da defesa do monismo por Parménides 179 (ns. 19, 20), citando Mourelatos, The Route..., 130-133; J. Barnes, The Presocratic..., 162; e P. Curd, "Parmenidean Monism", Phronesis 36, 1991, e The Legacy of Parmenides: Eleatic Monism and Later Presocratic Thought. Vide ainda R. D. McKirahan Jr., "Zeno", Id. 157, n. 15. Pelo contrário, D. Sedley, Id., 121, aparentemente toma a referência a uma única entidade como prova de monismo.

8 "Cada coisa que é "só pode ser uma coisa, só pode suportar um único predicado atribuível a todas as coisas e de modo particularmente forte": vide John Palmer, Plato's Reception of Parmenides, Oxford 1999, 91-92, citando Patricia Curd, "Parmenidian Monism", 241-264 (vide 242-243); da Autora, ver ainda, "Parmenides and After: Unity and Plurality", A Companion to Ancient Philosophy, M. L. Gill (ed.), Madison, London 2006, 39-42.
} 
Journal of Ancient Philosophy Vol. III 2009 Issue 2

eleático um carácter substancial. Se ““‘quilo” que é” é “o que pode ser pensado", nada aponta a uma entidade definida, nem à propriedade comum a todas as coisas que são.

De momento, B2 informa o leitor apenas de que, se só o que é é pensável, tudo aquilo de que se poderia pensar e dizer "não é" será impensável e indizível. Entendendo “o que não é" como o contrário de "o que é" - pois, só há dois pensamentos -, "o que é” constitui a unidade do que pode ser pensado e é, na totalidade das leituras de 'ser' que o verbo grego congrega.

\subsection{A identidade}

Entendido B2, levanta-se o problema posto pela sua inserção de B3 no Poema. Diels colocou-o a seguir a B2, como se resultasse diretamente da eliminação de "não é". Contudo, nada no texto fundamenta essa decisão; pelo contrário, a conclusiva 'gar', aparenta remeter para um verso anterior, que falta ${ }^{9}$. No entanto, a leitura veritativa permite, ao aceitar o argumento de B2, associar "pensar" e "ser". Se apenas "o que é" "pode ser pensado", então "o mesmo é ser e pensar" (B3).

Mas as maiores dificuldades residem no sentido a atribuir à identidade, expressa por to auto. Aplicando a B2 as duas leituras de "é" e "não é" apresentadas acima, o verbo tanto pode referir a totalidade de "o que é", como o todo constituído por cada uma das coisas "que é". Mas é evidente que as duas leituras implicam identidades muito diferentes:

“Tudo o que é é pensável";

"Cada coisa que é é pensável".

Um segundo problema reside no sentido dos dois infinitivos identificados. Como traduzir "noein” e "einai”? Será preferível a tradução direta: "pensar"10 e "ser"; ou, seguindo o sentido dativo do infinito, dever-se-á importar para B3 a construção

\footnotetext{
${ }^{9}$ J. Mansfeld, Die Offenbarung des Parmenides und die menschliche Welt, Assen 1964, 82, chegou a advogar a inserção de um verso entre B2.8 e B3.

${ }^{10}$ Há que não esquecer a lição de K. Von Fritz, "Nous, Noein, and their Derivatives in PreSocratic Philosophy (excluding Anaxagoras)", The Pre-Socratics, A. P. D. Mourelatos (ed.), Garden City, New York 1974, 23-85. Noein significa mais "conhecer", "apreender", "compreender", do que "pensar", no sentido do raciocínio lógico (45-52).
} 
Journal of Ancient Philosophy Vol. III 2009 Issue 2

potencial, de B2. $2^{11}$ ? Também aqui é manifesta a diferença de sentido da identidade nas duas traduções:

"o mesmo é pensar e ser";

"o mesmo é o que pode ser pensado e ser"

Pois, enquanto no primeiro caso é afirmada a identidade das duas entidades pensar e ser (adiante, “o pensar" e "o ser": B6-1) -, no segundo, indica-se que o objeto do pensamento (uma qualquer unidade) é ao mesmo tempo o sujeito do $\operatorname{ser}^{13}$.

É, porém, manifesta a tendência para associar a leitura potencial à tradução partitiva de "é", visto "o que pode ser pensado e ser" se aplicar a cada uma das coisas, enquanto, pelo contrário, a tradução normal dos infinitivos sugere que o pensar e o ser se referem a unidades cuja identidade é globalmente afirmada.

Só depois de resolvidas estas dificuldades é possível questionar o sentido da identidade expressa em B3. Deveremos pensar numa identidade abrangente, que tornaria "ser" e "pensar" indiscerníveis? Ou numa identidade gradual, incoativa, em que, distinguindo as duas entidades, se afirma que o "pensar" tende para o "ser"? Esta leitura é sugerida pela reiteração da identidade, em B8.34, de "pensar" e da "causa do pensamento" 14 (houneken esti noêma). Note-se, por outro lado, que a leitura partitiva

${ }^{11}$ J. Burnet, Early Greek Philosophy, London $1930^{4}$, 173, n. 2; seguido por largo número de tradutores e comentadores: F. M. Cornford, Plato and Parmenides, London and Henley 1939, 31; Kirk e Raven, Os filósofos pré-socráticos, Lisboa 1979, 275; W. K. C. Guthrie, A History of Greek Philosophy II, Cambridge 1965, 14; L. Tarán, Parmenides. A Text with Translation, Commentary, and Critical Essays, Princeton 1965, 41; todos indiretamente apoiados em Kühner-Gerth, Ausfürliche Grammatik der griechischen Sprache, 2. Teil, Satzlehre, HannoverLeipzig 1898-1904.

${ }^{12}$ A diferença é ainda mais notável em inglês, devido à tendência para adjetivar o pronome substantivado: "a mesma coisa" ("the same thing"). Vejam-se Burnet, Cornford, Kirk e Raven, acima, seguidos por muitos outros. Veja-se ainda o elegante compromisso: "Pois é a mesma coisa o que é pensado e o que é" (D. O'Brien, "Essai critique, Introduction à la lecture de Parménide: les deux voies de l'être et du non-être", in Aubenque (dir.), Études sur Parménide, Vol. 1, Paris: Vrin, 19-20).

${ }^{13}$ É essa a posição de J. Mansfeld, Die Offenbarung des Parmenides und die menschliche Welt, 67, apesar da tradução que propõe: "Denn Denken und Sein sind dasselbe".

14 A. P. D. Mourelatos, The Route ..., "Mind's Commitment to Reality", 164-193 (vide Simplício, in Phys. 87.18: to eon é o telos do pensamento). Talvez não haja grande diferença entre uma e outra interpretação se pensarmos que todos quantos se referem ao laço que une pensamento e ser (a começar por K. von Fritz, Op. Cit. 47; continuando com Patricia Curd, "Eleatic Arguments, Method in Ancient Philosophy, Oxford 1998, 19) se referem a essa "ligação essencial" do pensamento ao ser, a esse "pensamento acabado" a que Aristóteles chamará 
Journal of Ancient Philosophy Vol. III 2009 Issue 2

escapa a esta dificuldade remetendo a identidade para cada coisa "que pode ser pensada e ser".

A dificuldade da leitura global de "é" manifesta-se aqui, na confusão entre a leitura do pensamento como condição necessária ou suficiente. Pois, parece excessivamente difícil sustentar que ser e pensar são o mesmo, como se bastasse pensar, ou "conhecer" [algo] para que fosse (ou existisse).

Não será, porém, forçoso ler B3 deste modo, pois, a identificação do pensar com o ser se limita a enunciar a exigência a que todo pensamento deve obedecer. Será contudo, necessário determinar o alcance desta regra; questão que será considerada adiante.

\section{B6-B7}

2.1. Identidade e disjunção

B6 começa com um alargamento implícito da identidade. Sem que se repita que são o mesmo, “dizer", "pensar" e "ser" aparecem associados e identificados pela necessidade de "serem" (B6.1a). A identidade é necessária porque "pode ser" (B6.1b: de novo, a construção potencial), enquanto "nada não é" (B6.2a). Reforçando a dominância da leitura veritativa do verbo, B6.1a sustenta que a associação de "dizer, pensar e ser" tem de "ser (verdade)", porque "pode ser (verdade)".

Interrompo aqui a análise para focar o problema posto pela lacuna de B6.3b.

\subsection{Transição e lacuna}

Tanto a identidade implícita em B6.1a, como a disjunção entre B6.1b e B6.2a reiteram as lições colhidas em B2. Expostas estas, a deusa faz uma pausa e, num breve comentário, introduz uma primeira injunção: o destinatário da mensagem deve

"produtivo". Quanto à tradução de B8.34, recordo a sedutora leitura de G. Calogero: "a mesma coisa é o pensar e o pensamento que é" (Studi, 13). 
Journal of Ancient Philosophy Vol. III 2009 Issue 2

"meditar" no que the foi dito (B6.2b). Decerto, com o intuito de sintetizar numa cláusula a ordem dada, no verso seguinte refere uma "primeira via de investigação"15.

Ocorre então, na segunda parte da injunção, a lacuna que constitui a crux que separa os intépretes. Recorrendo ao paralelo com B7.2, Diels propõe "afasta-te" (eirgô: B6.3). Porém, recentemente, N.-L. Cordero tem vindo a contestar vigorosamente esta conjetura, que mostrou apoiar-se num erro, no que foi seguido por A. Nehamas ${ }^{16}$.

Este juízo é inquestionável, tendo, a meu ver, constituído a mais significativa inovação crítica na leitura do Poema, desde Rheinhardt ${ }^{17}$. Todavia, a emenda proposta arxei, "começarás" (arxô, para Nehamas: 131) - parece ser objeto de crítica análoga à dirigida a Diels: é fraca demais para justificar uma interpretação global do sentido do Poema.

Contra estas interpretações, neste ponto, defendo ser aconselhável atermo-nos ao que sabemos e ao que ignoramos. Declarada esta injunção, da qual a segunda parte nos escapa, segue-se-lhe uma invetiva demolidora contra o "pensamento errante" (B6.6) dos mortais (B6.4b-9), cuja força não é possível ignorar.

\subsection{O "terceiro caminho"}

O mais poderoso argumento de Cordero contra a interpretação proposta por Diels é o de que, sobre a disjunção de B6.1b-2a, o pensamento dos mortais se constituiria como um terceiro caminho, ao lado dos dois enunciados em B2. Não só a opção entraria em ruptura com toda a estrutura disjuntiva que atravessa o Poema, como tornaria incompreensível a remissão para B2.

\footnotetext{
${ }^{15}$ Uma vez que B6.3a ecoa B2.2, é legítimo supor que se refere aos "dois caminhos": "é" "não é". Uso o termo "injunção" para designar as recomendações, mais ou menos peremptórias, com que a deusa pauta a apresentação do argumento, que passo a enumerar. No proêmio (B1.24-32), a instrução de que o jovem deverá aprender tudo; na Via da Verdade, o início e o final de B2, B4, B6.2b-3, B7.1-5, B8.12-18, 36-39.

${ }^{16}$ Erro que remonta à edição Aldina do Comentário de Simplício ao Livro I da Física de Aristóteles (Veneza 1526): N.-L. Cordero, Les deux chemins de Parménide, Paris 1984, 132147 (140, n. 120), antes em "Les deux chemins de Parménide dans les fragments 6 et 7", Phronesis 24, 1979, 23. Ver ainda A. Nehamas, "On Parmenides' Three Ways of Inquiry", in Virtues of Authenticity, Princeton 1999, 125-137.

${ }^{17}$ K. Rheinhardt, Parmenides und die Geschichte der griechischen Philosophie, Bonn 1916. A obra foi responsável pela revalorização do Proémio do Poema.
} 
Journal of Ancient Philosophy Vol. III 2009 Issue 2

Não me parece, contudo, que seja forçoso extrair tal conclusão da análise de B6. Pode bem ser que, após a reiteração da disjunção, em B6.1-2a, a invetiva "seguinte" (epeit': B6.4a), contra os mortais, se constitua como o segundo braço de uma nova disjunção proposta ao ouvinte (B6.4-9), da qual a disjunção anterior (B6.1-2a) seria o primeiro.

Deste modo seria respeitada a forma diádica da argumentação. Em causa na alternativa entre estes novos "dois caminhos" achar-se-iam, de um lado, a contraposição de "é" a "não é", do outro, a conjunção dos caminhos opostos, expressa em B6.8-9a (Simplício fís. 78,2: DK28B6.8-9):

"para quem é costume ser e não ser serem o mesmo

e não mesmo...".

Por outro lado, é esta mesma tese que B7.1-2 confirma e reforça. A veemente proibição (ou gar mêpote: B7.1a) de "impor que são coisas que não são" (einai mê eonta: B7.1b), reforçada pela proibição de B7.2 - "afasta desta via de investigação o teu pensamento" - atinge diretamente o pensamento dos mortais (vide infra B8.40b). Na multiplicidade das leituras que a conjunção do infinito com a negação do particípio de einai consente, a falta denunciada é a contradição. O erro dos mortais é não respeitarem a oposição dos dois primeiros caminhos, consentindo na contaminação de um pelo outro.

\subsubsection{O complexo da doxa}

Os restantes três versos de B7 confirmam o diagnóstico insinuado pela deusa sobre a causa da errância (B6.5a: plattontai) dos mortais de duas cabeças (dikranoi). É o recurso aos olhos e ouvidos e língua (B7.4-5a) - em correspondência com "surdos e cegos" (B6.7a) - que a caracteriza, em dois planos distintos, mas complementares (Sexto Adv. math. 114.: DK28B8). Pois, numa síntese que prepara a abordagem da Via da Opinião, o tema d'“as aparências" (ta dokounta: B1.31) anuncia o enlace da sensibilidade nos:

"nomes que os mortais instituíram, convencidos de que são verdade: 
Journal of Ancient Philosophy Vol. III 2009 Issue 2

nascer e perecer, ser e não ser $^{18}$...” (B8.38-41; vide B19).

\subsection{Nova injunção}

Será, pois, contra o complexo da doxa - "o costume muito experimentado" que os versos 5-6a, que rematam B7 e conduzem a B8, contêm mais uma injunção que a deusa dirige ao jovem:

"decide pelo argumento (logôi) a prova muito disputada 19

de que falei."

Esta injunção anuncia o futuro que se depara à filosofia. Toda a tarefa do homem sabedor não consistirá mais em expressar simplesmente as suas opiniões, mas em usar a argumentação para debater, controverter, as teses que lhe forem propostas. É em obediência a esta ordem que a tradição cosmológica começa, primeiro, por registrar o impacto da argumentação eleática, para depois ser afastada pela concentração da pesquisa no exame das consequências que a aceitação da mensagem de Parmênides traz para a investigação do real.

\subsubsection{Recapitulação}

Com a sequência B6.4-B7, o Poema de Parmênides entra no mundo dos mortais. Por um momento, o argumento é suspenso e esquecidas as abstrações em torno das quais até aí girava. É então que se percebe que "ser" e "pensar", “é” e "não é”, serviram para, revelando a natureza do pensar, montar a crítica ao "pensamento errante" que os homens forjaram para explicar o mundo em que vivem; para mostrar que o ser não se encontra entre os sensíveis (Plotino En. V.1.8.15-17: DK28B3), sendo impossível chegar a ele pelo exercício da doxa.

\footnotetext{
${ }^{18}$ Seguindo a leitura proposta por L. Woodbury, "Parmenides on Names", Essays in Ancient Greek Philosophy I, J. Anton, L. Kustas (eds.), Albany 1971, 145-162; vide Mourelatos, The Route..., 181-183. De Woodbury recolho ainda a referência do tôi, de 8.38, ao ser dos versos precedentes (149). A importância desta leitura reside na contraposição implícita da convicção de verdade dos nomes postos pelos mortais ao ser, causa do pensamento.

${ }^{19}$ Contraposta ao "costume muito experimentado" (B7.3; vide Sexto Empírico adv. math. VII 114).
} 
Para tal, há que entender a ordem das disjunções. Em B2, o pensamento "é" opõe-se a "não é". Em B6.1-2, a reiteração e alargamento da identidade, que necessariamente "é" porque "pode ser", opõe-se a "nada", que "não é”. Essa disjunção é seguidamente contraposta à conjunção de "é e não é", resultante do recurso ao exercíco da doxa, que caracteriza o pensamento dos mortais (Simplício fís. 117,2: DK28B6). B7 confirma esta contraposição, associando a proibição da contradição à denúncia da sensibilidade, para finalmente a opor à prova muito contestada, decidida pelo argumento.

O sentido de todo este esquema será explicado adiante. Como o início da Via da Opinião tornará claro, a conjunção dos caminhos opostos, - a "enganadora ordem cósmica" (B8.52; ver B4.4) - não é mais do que o resíduo das percepções humanas, fixado em "saberes" (gnômas onomazein) pelos nomes das formas opostas: "fogo" e "noite" (B8.53; 57-63). Mas os indícios que confirmariam ser esse o sentido da Via da Opinião mostram-se excessivamente esparsos para serem aproveitáveis.

No entanto, se assim é, é para este mundo, o das opiniões humanas, que a deusa quer chamar a atenção. Não há como pensá-lo enquanto os homens se limitarem a vê-lo, ouvi-lo e dizê-lo. A Via da Verdade revela a natureza do pensamento, mostrando que, para respeitar a sua consistência, há que partir do primeiro e único caminho restante: "é".

$\mathrm{O}$ argumento da deusa obriga os homens - e não os mortais! ${ }^{20}$ - a decidirem (B7.5, B8.15): pensando "é" nunca poderão chegar ao mundo físico; vendo, ouvindo e falando nunca poderão chegar ao pensamento. Como podem então nomear as "aparências", ignorando que todas elas se referem ao ser (B8.42-45)? Ou supondo que, se uma das formas é, a outra não é (B8.57-65)?

Levanta-se então a pergunta acerca da realidade que se poderá atribuir à ordem descrita em B8. Como se deverá entender e aceitar a estrutura do argumento que fez a tradição pré-socrática infletir numa nova direção e deu origem à filosofia, como é conhecida desde então? Dever-se-á atribuir valor ontológico a um argumento dedutivo, construído a partir de premissas estabelecidas pela análise das relações entre ser, dizer e

\footnotetext{
${ }^{20}$ Deve distinguir-se a condenação dos mortais e das suas opiniões - brotôn doxai - da menção dos homens (anthrôpoi), cujo pensamento resulta das mistura dos seus "membros" (B16.1-2; ou seja, "sentidos").
} 
pensar? Para responder a estas perguntas, primeiro, há que entrar em B8 e estabelecer a identidade do ser; depois, que avaliar o modo como Parmênides é recebido pela tradição grega.

3. B8: o caminho do ser

A interpretação de B8 não é tão fértil em controvérsias quanto a dos fragmentos que o antecedem. Na sua terceira fase, o argumento enumera os "sinais" (B8.2) de que o ser é:

1. "ingênito e indestrutível", "uno", "homogêneo" (B8.3-21);

2. "contínuo e indivisível" (B8.22-25);

3. “imóvel (e imutável: B8.26-31);

4. "completo" (B8.32-33; 47-49.

$\mathrm{O}$ argumento deve fornecer as bases em que se apoiará a controvérsia contra os que defenderão cada uma das premissas negadas. Não creio que interesse muito identificar os seus destinatários já que a concepção que Anaxágoras (DK59B1-B12) extrai de Anaximandro $^{21}$ (DK12B1) e persiste em Leucipo (DK67A1) pode ser considerada como o modelo cosmológico dominante na tradição pré-socrática. É indiscutível que a suposição de que os contrários se geraram a partir de um qualquer “indefinido/ilimitado" viola a totalidade das teses avançadas por Parmênides em B8.

Esta conclusão é bastante para reforçar o ponto de vista exposto, de que, na análise de B8, a principal dificuldade do intérprete reside em saber de que está Parmênides a falar quando usa a expressão to eon. Pode ou não ser atribuído ao ser eleático uma dimensão ontológica? Constituirá um cosmo? Que relação manterá com estoutro em que vivemos?

3.1. A natureza do "ser"

${ }^{21}$ Ou de Hesíodo, vide M. Miller, “Ambiguity...”, 8-11. A presença da visão hesiódica do Tártaro, da Teogonia, será a seguir pormenorizadamente analisada, em contraste com o Apeiron de Anaximandro, na interpretação do proêmio do Poema. 
Um ponto me parece inquestionável. Se o ser descrito em B8 se refere a um mundo, este pouco ou nada tem a ver com o nosso. Desta constatação nasce a pergunta sobre quais serão a origem e a finalidade da concepção proposta.

Não há dúvida de que para esboçar a sua concepção do ser Parmênides não parte da observação do mundo visível; bem pelo contrário, B6-7 torna bem claro que a estrutura contra a imagem do mundo corrente entre os homens. A única indicação que dá ao ouvinte sobre uma possível origem da sua concepção de "o que é" acha-se em B2, cujo ponto de partida é sem dúvida a sua abordagem do "pensamento". Todavia, se o posicionamento do "dizer" ao lado do "pensar" e do "ser", em B6.1a, sugere que toma a linguagem como a via de acesso ao pensar, não será infundado sustentar que a unidade semântica de einai, determinante do funcionamento do verbo na linguagem, é o modelo de que parte para estruturar a sua concepção do "ser".

Concluo daqui, que "o que é" só pode ser entendido como o referente do pensamento. Cabe, portanto, perguntar se a interpretação da argumentação eleática sobre o ser como uma teoria sobre uma entidade ideal é ou não confirmada pela influência abrangente que exerce sobre toda a tradição.

II. A recepção de Parmênides pela tradição

\section{Os pós eleáticos}

A influência do Eleata nos pensadores gregos é perceptível por vagas, concentradas ora nuns, ora noutros fragmentos. A tradição cosmológica pós-eleática concentra-se em B8 para aplicar a argumentação eleática ao mundo físico. Sem considerar Zenão, cujos argumentos executam finalidades polêmicas, o primeiro sinal da presença de Parmênides na tradição acha-se nos fragmentos de Melisso. Em particular, os fragmentos 7 e 8 contrapõem a argumentação sobre os "sinaIs" do ser à imagem que os sentidos, organizados pela experiência e pela linguagem, dão do mundo. Por um lado, reforçam o dualismo; por outro, deixam aberta a via que conduz ao atomismo.

[Comentando a mudança dos corpos sensíveis] "Eles não mudariam se fossem reais; cada coisa seria tal como nos parece ser, pois, nada é mais forte que o ser. 
Mas, se aconteceu ter mudado, o que é pereceu e o que não é foi gerado. Deste modo, se houvesse uma pluralidade, as coisas teriam de ser como o um" (Simplício Do céu 558,21: DK30B8).

Também não será difícil documentar a presença de B8, do Da natureza, em diversos fragmentos de Empédocles, de Anaxágoras e dos Atomistas, condensada em particular na proibição da gênese e corrupção, justificada pela sobreposição da identidade ao movimento/mudança, e do vazio. Dois problemas são evidentes: como pode algo que "é aquilo que é" mudar, ou até receber predicados que diferem de "o que [ele] é"?; como pode o não ser existir ${ }^{22}$ ?

Em todos estes pensadores é patente a tendência para adaptarem os seus postulados à crítica a que o argumento eleático submete as teorias cosmológicas, difundindo a ideia de que a explicação da gênese do cosmo deve aceitar a argumentação de B8. A consequência, que não detecto no Da natureza, é a "fisicalização" do ser de Parmênides $^{23}$.

Mas, será que a tentativa de compatibilizar as teorias sobre a gênese do cosmo com a argumentação eleática implica que a concepção do ser, desenvolvida em B8, se refere ou aplica ao mundo físico, como ele é, ou como deve ser entendido?

\section{Os sofistas}

Contradizendo esta possibilidade, a maior prova de que o ser de Parmênides exprime uma exigência do pensamento, tal como a linguagem o expressa, acha-se nos sofistas. Considerarei primeiro os fragmentos que deles nos chegaram - o que implica conceder a primazia a Górgias -, para a seguir abordar as referências colhidas dos diálogos de Platão, onde a presença de Protágoras incontestavelmente domina.

\footnotetext{
${ }^{22}$ Segundo Plutarco, Adv. Col. 4, 1180F (DK68B156), Demócrito contesta este princípio eleático: "o ser (den) não é mais do que o não ser (mêden).

${ }^{23}$ Será talvez essa a principal motivação para referir B8 à realidade. Por exemplo, D. Sedley, "Parmenides and Melissus", Cambridge Companion to Early Greek Philosophy, 121-123, defende a espacialidade de to eon, a partir de argumentos apresentados em B8.48 ("maior/menor", "aqui/ali"). Não me parece, contudo, que a negação do fato de haver mais ser aqui do que ali implique que o ser exista neste mundo, ou constitua qualquer outro. Por outro lado, interpreto a referência à esfera como uma imagem sugestiva. Solana Dueso, Op. Cit., 103, cita, em apoio antigo desta leitura, Simplício, fís. 147,1).
} 
Journal of Ancient Philosophy Vol. III 2009 Issue 2

\subsection{Górgias}

Defendo que a influência de Górgias no pensamento grego, condensada nas suas contribuições para a erística, a dialética, a cosmologia e até a Física ${ }^{24}$, é muito mais profunda do que aquela que a generalidade dos comentadores até há pouco lhe concedeu $^{25}$. Vou concentrar-me pontualmente nas duas súmulas que nos chegaram do seu tratado Da natureza ou do não ser, registradas por Sexto Empírico (Adversus mathematicos VII 65-87) e Pseudo Aristóteles (De Gorgia 979a13-980b21).

O mais importante indício que se poderá colher da sua importância tanto em Sexto $^{26}$ (DK82B3.77-82), como no Pseudo Aristóteles (De Gorgia 980a9-b11: B3a), acha-se na refutação da possibilidade de, a partir do Da natureza, chegar ao conhecimento do ser. Para argumentar a favor da impossibilidade de atingir o ser, Górgias usa a lógica eleática, a partir da análise da experiência humana do pensamento. O seu objetivo não é mostrar como é possível pensar o mundo exterior, mas, pelo contrário, questionar a possibilidade de, através do pensamento e/ou da linguagem, o vir a atingir de todo ${ }^{27}$.

A versão de Sexto, acha-se claramente dividida em três partes. Na primeira (6576), o sofista usa os dois caminhos de Parmênides, opostos pela leitura da negativa como contrariedade, para provar que nada é. Consegue a sua prova mostrando que a atribuição ao ser de qualquer par de predicados contrários gera insanáveis contradições.

\footnotetext{
${ }^{24}$ Veja-se a influência de Górgias B3.69-70 no cap. 5 do Livro $\Gamma$ da Física, de Aristóteles (204a8-206b8). Caracerística do estilo gorgiânico é a argumentação em dois braços antitéticos (parodiando Parmênides B2), cada um dos quais conduz a consequências inaceitáveis.

${ }^{25}$ Veja-se o tratamento comprimido que recebe da parte de influentes comentadores como: W. Guthrie, A History of Greek Philosophy III, Cambridge 1969, 269-273; J. D. Rankin, Sophists, Socratics and Cynics, London and Canberra 1983, 35-45, 92-95. A excepção será: G. Kerferd, "Gorgias on Nature and that which is not", Phronesis 1, 1955, 1-25. Pelo contrário, a sua influência na Retórica nunca foi contestada, achando-se devidamente reconhecida e bem estudada.

${ }^{26}$ Mas note-se como a argumentação de Sexto segue de perto a de Górgias: Adv. Math. I.1-40.

${ }^{27}$ Ver ainda, no Elogio de Helena, a compensação desta impotência da razão pelo uso da Retórica: "O discurso é um grande senhor, que com um corpo pequeno e imperceptível levou a cabo tarefas divinas" (B11.8). Independentemente da possibilidade de captar a realidade pelo pensamento, certo é que a perícia do orador investe o discurso do poder de a moldar a seu bel prazer, produzindo efeitos no comportamento da sua sua audiência.
} 
Na segunda (B3.77-82), constitui a faculdade a que chamamos "pensamento" a partir do fato de haver "coisas pensadas", globalmente entendidas como percebidas, imaginadas ou inteligidas pela diversidade dos homens. $\mathrm{O}$ argumento é apresentado na forma de um dilema: "se as coisas pensadas (ta phronoumena) não são seres, o ser não é pensado..." (77); se, por outro lado, "as coisas pensadas são seres, todas as coisas pensadas são e do modo em que alguém as pense" (79; seguindo com os conhecidos exemplos de "um homem voando" ou "carros correndo sobre o mar").

Em B3a, o argumento é ainda mais elaborado: se o ser é cognoscível, "todas as coisas pensadas devem ser $^{28}$, e o não ser, uma vez que não é, não pode ser pensado. Mas então, ... ninguém poderia dizer nada falso"... (segue o exemplo dos "carros correndo no mar"). "Pois, todas as coisas seriam o mesmo. Tanto as vistas, como ouvidas, por isto seriam, por cada uma delas ser pensada". Se, pelo contrário, "aquilo que vemos não é porque o vemos, então, o que pensamos não seria porque o pensamos...”. Logo, o ser não é cognoscível (980a9-17). E o tratado termina com uma referência críptica à influência, em Górgias e noutros, de "outros pensadores mais antigos" (980b21), que penso só poder visar Parmênides.

\subsection{Protágoras}

Mais provas de que as concepções epistemológias dos sofistas construíam a realidade a partir do pensamento acham-se nos diálogos que Platão dedica a Protágoras quer avaliando-o individualmente, quer nos passos em que o associa a outros sofistas. No Crátilo (385e-386a, c) e no Teeteto 161c, Sócrates sustenta que o sofista partia da tese segundo a qual "o homem é a medida de todas as coisas, das que são, como são, das que não são, como não são" (152a), para defender que "as coisas são para cada um como lhe parecem" (152a) e que "as opiniões dos homens são sempre verdadeiras" (170c).

\footnotetext{
${ }^{28}$ Nos sentidos identitativo, predicativo e existencial, como atesta a apresentação do argumento de Górgias: "se o não ser é não ser, e o ser [é] ser, as coisas (pragmata) são nada mais do que não são" (B3a: Aristóteles De Gorgia 979a27-29).
} 
A associação das três teses é confirmada por Sexto Empírico, Adv. math. VII 60, no contexto que introduz o fragmento citado por Platão (DK80B1), embora neste último não se faça qualquer referência a "opiniões".

Aceitando a associação das três teses, é oportuno compará-las com os argumentos de Górgias. Aparentemente Protágoras não alinha com qualquer das alternativas da argumentação de Górgias tanto a construída a partir de "é" e "não é", quanto a que estabelece a inacessibilidade do pensamento a "o que é", limitando-se a apontar a sua irrelevância no processo doxástico. Introduz, portanto, alguns refinamentos interessantes.

É ao complexo da doxa - percepção, imaginação, pensamento, opinião - que cabe a tarefa de configurar a imagem do mundo exterior e a experiência individual. Não parece haver problema em aceitar que as coisas (chrêmata: vide De Gorgia 979a28; pragmata) sejam, nos sentidos existencial e predicativo, tais como cada um as recebe. É, porém, difícil admitir que possam "ser" ou "não ser", no sentido identitativo ${ }^{29}$, pois não é considerada a possibilidade de se poder falar de "coisas" a partir da percepção que cada um tem delas (vide Teet. 152d, 156a-157c, especialmente no final ${ }^{30}$ ).

A comparação das teorias dos dois sofistas mostra ser duvidoso apontar qual deles será mais radical. Se bem que ambos insistam na estrita dependência do ser em relação ao pensamento, o teor erístico do tratado de Górgias obriga-o ao menos a referir o ser, enquanto Protágoras o recalca de todo. Ultrapassando a cisão eleática, o sofista elimina qualquer possibilidade de conflito interno entre as faculdades perceptivas e judicativas, apoiando essa eliminação no argumento da infalibilidade da sensopercepção $^{31}$.

Numa leitura superficial, a tese que defende a verdade de todas as opiniões apoia-se na falácia preferida dos sofistas, a secundum quid: as opiniões serão verdadeiras apenas para quem as emite, e não simpliciter. O cancelamento da cláusula

\footnotetext{
${ }^{29}$ Note-se, no Teeteto (152d-e) a invocação do fluxismo de Heraclito para permitir a associação da infalibilidade da percepção (152c) à diversidade da experiência senso-perceptiva.

30 Os referentes dos nomes comuns são meros "agregados" (athroismata), feixes de propriedades evanescentes.

31 "Uma percepção é sempre do que é e é infalível (apseudes), sendo saber" Teeteto 152c5. Vide G. Fine, "Conflicting Appearances: Tht. 153d-154b", Form and Argument in Late Plato, Chr. Gill and M. M. McCabe (eds.), Oxford 1996, 105-133 (esp. 129-133).
} 
constitui a falácia, pois, é evidente que quem considera verdadeiras as suas opiniões ipso facto considera falsas todas aquelas que discordam delas ${ }^{32}$.

Admitindo que Protágoras não cometeu o erro de pensar o contrário, a sua tese se, de fato, ele a avançou - deve ou ser naturalizada pela adjunção da cláusula relacionalista (e não "relativista"), ou equivaler à desqualificação de qualquer critério externo de validação da experiência (Teet. 167a). Pois, foi nessa mesma linha que Sócrates a abordou pouco antes, na chamada "defesa de Protágoras" (Teet. 166a-168c). O paradoxo, que Sócrates explora até às últimas consequências na chamada "autorefutação de Protágoras", reside em aplicar o termo "verdade" às opiniões individuais ora para deflacionar o conceito, ora para inflacioná-lo até o tornar redundante ${ }^{33}$.

Dela se podem extrair três conclusões:

1. a reinterpretação das teses do sofista permite preservar a sua coerência e consistência;

2. "a verdade" é subsumida na concordância do ser com o parecer ${ }^{34}$, não se manifestando como "adequação" ao real;

3. não há "verdade" e "falsidade", mas estados de alma "melhores ou piores": íntimos ("saúde"/“doença", etc.), ou inseridos num contexto social (valores éticos, leis, etc.): Teet. $167 \mathrm{a}-\mathrm{d}$.

Duas consequências podem ser extraídas desta leitura da tese de Protágoras: o discurso é submetido à autenticidade e privacidade do que cada um sente (2); as opiniões individuais são corrigidas pelos efeitos persuasivos do ensino (167c) e da pressão social (3).

\subsection{Outros sofistas}

\footnotetext{
${ }^{32}$ Este argumento é desenvolvido por Sócrates, no Teeteto 170a-171c.

${ }^{33}$ Vide W. Quine, Pursuit of Truth, Cambridge 1990; P. Horwich, Truth, Oxford 1990; R. Ramsey, "Facts and Propositions", reimpr. em Foundations of Mathematics, London 1931, 138155 .

${ }^{34} \mathrm{O}$ acordo íntimo do que cada um diz com o que pensa e sente: Teet. 166c-d: "a um umas coisas parecem e são, a outro, outras"; 167a: "é impossível [alguém] opinar além do que sente". Portanto, não há como apelar para um "real", um "ser" independente daquilo que cada um percebe. No final da argumentação contra Protágoras, Sócrates autocritica-se, admitindo a dificuldade de refutar estas teses: Teet. $179 \mathrm{c}$.
} 
Análoga abordagem da submissão da realidade exterior à experiência cognitiva proporcionada pelo pensamento e pela linguagem é patente nas teses atribuídas a Eutidemo sobre a impossibilidade de alguém "dizer falsidades", logo de cair em contradição no discurso (Eutidemo 283e-284c, 285d-286d).

$\mathrm{O}$ argumento pode ser avaliado de duas perspectivas: a partir da argumentação de Górgias, ou inserido na de Antístenes ${ }^{35}$. Como se viu atrás, o Leontino considera duas alternativas, uma e outra conduzindo à mesma conclusão: se as coisas pensadas são, não há falsidade; se não são, o pensamento não acede ao ser.

No Eutidemo, o ponto de partida é o discurso. Ou as coisas ditas são, ou não são. Se são, são verdade, e a falsidade é impossível. Se não são, há mais duas alternativas: ou quem diz coisas que não são não diz nada (286a2-3, c6-8); ou fala de outras coisas (286a3-5). Em todos os casos, é impossível dizer falsidades e ninguém se contradiz.

$\mathrm{O}$ argumento é apresentado em duas fases. Na primeira, o sofista argumenta a partir do fato de "dizer a coisa sobre a qual é o discurso" para dizer "coisas que são", logo, verdades, pois "aquele que fala" "diz o que diz", e quem "diz o que diz" diz "o que é"; concluindo que quem diz "as coisas que são" "diz a verdade". A despeito de duas graves distorções de Parmênides B7.1 ${ }^{36}$, nesta fase o argumento limita-se a deslocar a argumentação de Górgias do pensamento para o discurso ${ }^{37}$.

Na segunda fase, o argumento começa por forçar a identidade de "não é" a "não é de modo nenhum" (oudamou) para, ecoando o pragmatismo de Protágoras, se deslocar para um contexto performativo ("falar é agir": Eutid. 284b8-9), ao perguntar se os oradores nada fazem quando falam ao povo. Termina, reafirmando a identidade da verdade com "as coisas que são", da qual extrai a tese que confirma a impossibilidade da falsidade (284b-c; adiante, da ignorância, do erro e da refutação: 286b-287a).

\footnotetext{
${ }^{35}$ Vide S. di Camillo, "El problema del logos falso nel Eutidemo y su solución nel Sofista", Hypnos 19, 2007, 1-15 (vide 6-8, com as referências relevantes).

${ }^{36} \mathrm{O}$ texto platônico antepõe o artigo ta a mê eonta; a cláusula einai é cancelada. B7.1 proíbe impor mê eonta einai ("que são coisas que não são") e não ta mê eonta legein ("dizer as coisas que não são": Eutid. 284c3).

${ }^{37}$ Introduzindo duas falácias de referência: entre "falar" e "dizer" (falar sobre algo equivale a "dizer o que [algo] é"); entre alguém "dizer o que diz" e "dizer coisas que são" (a identidade do discurso ou o acordo do falante consigo mesmo implica a identidade e existência do objeto do discurso).
} 
Journal of Ancient Philosophy Vol. III 2009 Issue 2

Como sugeri atrás, esta linha de argumentação aplica o argumento de Górgias ao discurso, enaltecendo a sua dimensão performativa (Encômio de Helena: DK86B11.8): o poder do discurso permite ao falante criar fatos cuja relevância e consequência são socialmente inegáveis. Com esta recontextualização, mais do que a possibilidade, é erradicada a utilidade do acesso a uma realidade exterior à do próprio discurso.

Outra tese atribuída a Eutidemo, da qual se colhem sinais em Górgias (De Gorgia 980a12-13, acima), é a de que "todas as coisas são do mesmo modo para todos, ao mesmo tempo e sempre" (Crátilo 386d). Se todas as coisas "são" porque são percebidas por todos, não podem deixar de ser sempre como todos as percebem.

$\mathrm{Na}$ forma sucinta e não exemplificada em que nos chega, a tese combina as propostas da teoria do conhecimento de Protágoras com o niilismo onto-epistemológico de Górgias. Nada há para além das senso-percepções individuais, amplificadas pela experiência da comunicação social. No limite, a tese pode ser lida como a condensação numa frase da unidade semântica de einai.

\subsubsection{Antístenes}

Mas há outro modo de ler o argumento do Eutidemo. A falácia inicial, que equivoca entre "falar" e "dizer", pode ser vista como um outro equívoco: entre o logos como discurso, ou como nome da coisa. É esta última leitura que é consensual atribuir a Antístenes.

Embora não se possa considerá-lo propriamente um sofista, Antístenes poderá ser visado em dois importantes passos do Eutidemo e do Sofista. Manifesta a influência de Parménides B7.1 numa concepção que Aristóteles identifica como o "enunciado próprio" (oikeios logos: Metafísica $\Delta 29,1024 b 26-34$ : fragmento 47A, Caizzi ${ }^{38}$ ). Ao contrário do seu primeiro mestre, Górgias (o segundo foi Sócrates), Antístenes aparentava admitir a possibilidade de usar o discurso para se referir aos entes. Todavia, rejeitava a definição (horisasthai, horos) por considerá-la um "enunciado extenso"

38 Vide Alexandre de Afrodísias in Met. 1024b26, 434,25: fragmento 47B, Caizzi. Cito Antisthenis fragmenta, collegit Fernanda Decleva Caizzi, Milano 1966. 
Journal of Ancient Philosophy Vol. III 2009 Issue 2

(makros logos: Metafísica H3,1043b23-32 ${ }^{39}$ ), reduzindo a definição por acidente à definição essencial.

Aristóteles aceita a tese da unidade (hen eph'henos: Met. $\Delta 291024 b 33$ ) do logos (1024b29, 1044a6), mas critica Antístenes por impedir a explicação da unidade (por exemplo, pela determinação da matéria pela forma: 1043b30-32). Defende que além de definir cada coisa com o seu logos próprio, também é possível recorrer ao de outra (Met. $\Delta 29,1024 b 34-a 1)$.

A partir desta crítica é possível entender a concepção antisténica do logos "um sobre um" como a redução do enunciado ao nome. Nesse sentido, no Eutidemo 283e9, "dizer a coisa sobre a qual é o discurso" equivale a nomeá-la. Em consequência desta posição, é suspensa a exploração da ambiguidade de einai, resultante na defesa da impossibilidade de contradição pelo fato de toda a predicação ser reduzida à identidade ${ }^{40}$.

Tudo leva a crer que esta mesma é a concepção criticada por Platão quando, no Sofista 251c-d, refere aqueles que afirmam "que não se deve chamar bom ao homem, mas bom ao bom e homem ao homem". O que Platão denuncia como a proibição da "mistura dos gêneros" - que resulta na proibição da "participação num outro" (Sof. $252 b)$ - redunda na redução da predicação à identidade. A estratégia pode ser vista como a tentativa de superar a tensão entre identidade e predicação pela subsunção do predicado próprio no nome do sujeito ${ }^{41}$, a fim de evitar a ambiguidade.

\subsection{Avaliação das teorias atribuídas aos sofistas}

Durante séculos, as concepções cognitivas sofísticas foram encaradas como distorções da natureza do pensamento e do discurso pelo fato de usarem argumentos falaciosos para lhes negarem o valor referencial. É inegável que os contextos platônicos

\footnotetext{
${ }^{39}$ Vide Alexandre in Met. 1043b23, 553,29: fragmento 44B, Caizzi.

${ }^{40}$ Esta leitura permite explicar outro passo em que a possibilidade de contradição é negada. No Crátilo 429c-d, Crátilo justifica esta impossibilidade pelo fato de todo nome se aplicar a uma única coisa: não há nome falso, mas nome de outra coisa.

${ }^{41}$ Fazendo pensar na noção de "descrição", tal como Russell a propõe em vários escritos, nomeadamente em "On Denoting".
} 
Journal of Ancient Philosophy Vol. III 2009 Issue 2

em que algumas delas nos chegaram - nomeadamente o Eutidemo - dão essa ideia. Há, porém, sérias reservas a avançar tanto contra a redução simplista da sofística a um arrazoado de propostas insensatas, quanto contra a concentração no problema da referência.

Por um lado, diversas interpretações do diálogo relativamente recentes contribuíram para revelar a complexidade e riqueza do pensamento que ocultam ${ }^{42}$. Por outro, a repetida atenção que as teses atribuídas aos sofistas receberam nos diálogos sugere que desempenham função relevante na formação da epistemologia platônica.

Com esta hipótese chego a um novo problema. É indubitável que o conflito que opõe Platão aos sofistas parece girar em torno da exigência eleática da referencialidade do pensamento. Creio, contudo, não haver razões para ler maniqueisticamente o conflito, colocando do lado dos "bons" os referencialistas, e do outro os "vilões" irreferencialistas.

Tentarei a seguir separar os fios que tecem o confronto conducente à proposta da teoria da verdade como adequação. Defendo ser ele que constitui o problema nuclear em torno do qual se estruturam as sucessivas versões da concepção platônica de saber, que condensam o programa da chamada "versão canónica da teoria das Formas".

\section{Platão}

A influência direta e indireta de Parmênides em Platão, perceptível em citações, imitações, reconstruções (a segunda parte do Parmênides) e teses específicas, é excessivamente profunda e abrangente para ser documentada aqui ${ }^{43}$. Vou limitar-me a apontar os cinco momentos que considero mais relevantes da exposição de que é objeto,

\footnotetext{
${ }^{42}$ Vejam-se R. K. Sprague, Plato's Use of Fallacy: A Study of the Euthydemus and Some Other Dialogues, London 1962; N. Denyer, Language, Thought and Falsehood in Ancient Greek Philosophy, London 1991; T. Chance, Plato's Euthydemus: Analysis of What Is and Is Not Philosophy, Berkeley and Los Angeles 1992; John Palmer, Plato's Reception of Parmenides, Oxford 1999.

${ }^{43}$ Remeto para G. Prauss, Platon und der logischer Eleatismus, Berlin 1966, e J. Palmer, Plato's Reception of Parmenides. A interpretação aqui proposta diverge da deste último Autor em dois pontos: 1. ao não atribuir a Parmênides uma concepção referencialista do discurso; 2. ao negar relevância às formas extremadas - "o que é de todo o modo" e "de nenhum modo" (vide Eutid. 284b; República 477a - na leitura do argumento.
} 
para debater depois, em confronto com as leituras "sofísticas" de Parmênides, o impacto do argumento que percorre a Via da Verdade na filosofia platônica.

Um primeiro momento, notável no grupo de diálogos chamado "socrático", obedece à finalidade programática de desvalorizar o "saber humano" (Apologia 23a-b). Qualquer pretensão de saber expressa pelos interlocutores de Sócrates, condensada numa resposta à pergunta “o que é?”, invariavelmente acaba por ser refutada. O triunfo do filósofo é conseguido pela prova de que as respostas dadas à pergunta - na forma "A é B" - nunca conseguem satisfazer a exigência da identidade do definiendum ao definiens, imposta pela identificação do saber com “o que é” (Mênon 71a).

O segundo momento, que constitui o mais forte sinal da presença de Parmênides em Platão, é o da proposta do dualismo onto-epistemológico como explicação da natureza da realidade e apoio da possibilidade do seu conhecimento. Suportando a associação da "versão canónica da teoria das Formas" (TF) à reminiscência, o dualismo é em diversos contextos proposto nos diálogos (Fédon, República, Banquete, Fedro, Crátilo, Timeu) como o pressuposto de qualquer tentativa de abordagem ontoepistemológica do real. Enquanto a configuração do mundo e da experiência sensíveis reflete a recepção de B6-7, a caracerização do inteligível manifesta a sua dependência da argumentação de B8 (Fédon 72-76; República V-VII, X 595a-598d; Timeu 27d ss.).

O terceiro momento da presença eleática na obra platônica concentra-se no Parmênides e no Teeteto. O objetivo da crítica aí apresentada é questionar a solidez da estrutura abrangente da TF. São manifestas as dificuldades de, aceitando a lógica eleática, esboçar uma concepção da participação e da predicação, capaz de superar a cisão que opõe os planos onto-epistemológicos do sensível e do inteligível, viabilizando o trânsito da opinião para o saber.

A dificuldade pode ser expressa nas seguintes perguntas. Como é que o mesmo nome simultaneamente se refere à entidade e predicado epônimos e a cada uma das suas instâncias? Como podem os predicados transitar das Formas, que perfeitamente os exibem, para as naturezas sensíveis que deles recebem o nome e deficientemente os $\operatorname{captam}^{44}$ ?

\footnotetext{
${ }^{44}$ Como é possível que "F", cuja unidade "é aquilo que é", se manifeste como "f" - que "é e não é (F)" - nas unidades constituídas pelas multiplicidades sensíveis?
} 
Aceitando a lógica eleática como instrumento de análise do real, a quarta vaga do eleatismo nos diálogos responde a estas perguntas no Sofista. Afronta sucessivamente dois tipos de problemas inter-relacionados: de um lado, aquele que é posto pelos sentidos atribuídos a "ser" e a "não"; do outro, o da referência dos nomes comuns às entidades inteligíveis e às suas instâncias, bem como aos respetivos predicados.

Elegendo como programa criticar a máxima eleática - "não imporás que são coisas que não são" (Sofista 241d ss.; vide 237a: Parmênides B7.1) -, da qual resultam a impensabilidade, indizibilidade, impronunciabilidade e inexplicabilidade do não ser (Sof. 238c), a pesquisa propõe-se reformular a TF de modo a mostrar como "o que não é” de alguma maneira é. Para atingir esse objetivo será obrigada a dar conta de como os regimes das relações que as Formas mantêm entre si - inclusão, participação e exclusão (253d-e) - se expressam na linguagem pela participação das Formas ${ }^{45}$ do Ser, do Mesmo e do Outro, determinantes da "existência", da "identidade" e da "predicação" (254b-256e).

Finalmente, um quinto e último traço da influência de Parmênides manifesta-se na regulamentação dos aspetos do verbo einai pela tese do "eterno presente do ser" (Parmênides B8.5-24). Platão evoca-a no Timeu 37e-38b, inserida na sua descrição de como nasceu o Tempo. Enquanto "foi" e "será" são reservados àquilo que nasce e se transforma, "é" aplica-se apenas à entidade eterna (aidion ousia: 37e5; vide Parmênides B8.5, 20).

Sob a aparência de reforçar o dualismo, a teoria que opõe o sensível ao inteligível no domínio onto-epistemológico reformula a oposição das duas vias no Poema de Parmênides. Embora, ao longo do relato da cosmo/psico-gênese, Platão nunca afrouxe a distância que separa os dois braços do dualismo, enunciado em 27d-28a, tenta, através do "discurso plausível", viabilizar a articulação da deveniência das imagens que povoam o cosmo com a eternidade, perfeição e imutabilidade dos seus originais inteligíveis. Ao longo do relato, as Formas permanecem como expressão do ser e saber

\footnotetext{
${ }^{45}$ A reformulação da participação através da mistura das Formas propõe uma nova resposta para o problema da predicação, articulando o "mundo" da gênese com o da "entidade" (ousia: 248a254d). Vide A. Nehamas, "Participation and Predication in Plato's Later Thought", in Virtues of Authenticity, Princeton 1999, 196-223 (esp. 215-218); Eliana C. Souza, Discurso e Ontologia em Platão; uma leitura do Sofista, Ijuí 2009, 105-153.
} 
inteligíveis, os quais, através da alma, comandam os paradigmas sensíveis - Tempo, Espaço -, que conferem vida ao cosmo e garantem a regularidade dos seus movimentos.

\subsection{Qual é o referente das Formas?}

Examinando globalmente estas cinco vagas do eleatismo nos diálogos platônicos, só encontro sinais da possibilidade de explorar a dimensão física da teoria eleática do ser no argumento sobre a mistura das Formas, no Sofista. Fora desse argumento, enquanto um vínculo profundo identificar ser e saber na filosofia platônica, não será possível separar o conhecimento da realidade por ele visada.

$\mathrm{Na}$ análise da tradição cosmológica, no Sofista 242c ss., o Hóspede critica as teorias monistas e pluralistas expondo as aporias referenciais a que dão origem ${ }^{46}$, de modo de todo alheio ao da constituição física do cosmo. A ligação ao real é estabelecida através das Formas do movimento e do repouso, das quais tanto o sensível, quanto o inteligível participam. Trata-se, porém, de princípios explicativos.

Por outro lado, o "lugar inteligível", descrito no Fedro (245c ss.) deve ser entendido no contexto de uma narrativa mítica, não abonando a recepção platônica do ser eleático como uma teoria física.

\section{Aristóteles e a tradição doxográfica}

Embora a influência exercida pelo pensamento de Parmênides se estenda a toda a tradição filosófica, é nas obras dos pós-eleáticos e sobretudo nas de Platão que se acham condensados os contornos com que chegou à atualidade.

A retroação do platonismo sobre o pensamento de Parmênides explica-se pelo fato de a recepção atual do Da natureza ser maioritariamente devedora de Platão e dos doxógrafos platônicos e neo-platônicos: Plutarco, Proclo e Simplício, aos quais se devem acrescentar o cético Sexto Empírico e o filósofo Plotino.

\footnotetext{
${ }^{46}$ Para uma boa análise destas aporias e das dificuldades que as justificam, é imprescindível a leitura do capítulo "Dizer o que é," em E. C. Souza, Op. Cit., 73-104.
} 
Journal of Ancient Philosophy Vol. III 2009 Issue 2

A persistência deste efeito platonizante bastaria para secundarizar as divergências de interpretação introduzidas pelas obras de Aristóteles e do seu comentador, Alexandre de Afrodísias. Nota-se, no entanto, na leitura aristotélica de Parmênides uma aparente inconsistência, que poderá aportar dados que confirmem a hipótese, levantada atrás, de uma leitura não refrencial do argumento eleático.

As menções de Parmênides e dos eleatas nas obras de Aristóteles podem dividirse em dois grupos. De um lado acham-se as referências a traços da doutrina eleática; do outro, as críticas de que é objeto. Todas são importantes, embora por razões diferentes.

As primeiras informam-nos sobre os tópicos do pensamento eleático que o Estagirita considera mais relevantes, os quais ocasionalmente servem de contexto à citação de algum fragmento ${ }^{47}$. As segundas, reveladoras da contribuição das concepções eleáticas para a formação do pensamento de Aristóteles, acham-se concentradas nas violentas críticas desferidas contra a argumentação monista.

De acordo com o Estagirita, do fato de dizerem o ser "de uma só maneira" (Fís. A3,186a-187a3 ss.; Met. B4,1001a29 ss., N2,1089a2 ss.; Alexandre, metaph. 44,10 s.: vide DK28A27), Parmênides e os eleáticos extraem:

1. a proibição da geração e corrupção, e da multiplicidade (Fís. A8,191a24 ss.: DK28A24);

2. a defesa da unidade e imobilidade imutável da natureza (Met. A3,984a27 ss.: id.);

3. a oposição do ser ao não ser; este último identificado com o nada (A5,986b8 ss.: id.).

É no final deste último trecho que, sem transição, Aristóteles passa a referir-se a tópicos constitutivos da Via da Opinião. Sustenta o passo que, embora Parmênides pense que nada existe além do ser, "obrigado a seguir os fenômenos e a opinar que o uno é segundo o logos, e múltiplo, segundo as sensações", distingue duas causas e princípios: o quente e o frio, ou o fogo e a terra" -, alinhando uns do lado do ser, outros, do não ser (Id., Ibid. b31-987a2; vide G. C. A3,318b6, B3,330b13, B9,336a3: DK28A35). É caso para perguntar se não será inconsistente esta mistura das duas vias.

\footnotetext{
${ }^{47}$ O mais importante será B16 (Met. Г5, 1029b21), que Teofrasto comenta extensamente (De sensibus 1-3: DK28A46).
} 
Mas a inconsistência é aparente, pois, longe de querer confundir ou transformar o monismo eleático num dualismo, Aristóteles aponta a distinta proveniência de um e de outro: enquanto o primeiro se restringe à teoria epistêmica, o segundo é requerido para dar conta da diversidade dos fenômenos (vide Aristóteles Do céu Г1,298b19-25, GC A8,325a13-23: DK28A25; Plutarco Adv. Col. 13, p. 1114D; Simplício fís. 38,20; 25,15: DK28A34).

Com esta observação passageira - repetida pelos comentadores -, o Estagirita avança a sua hipótese sobre o encadeamento das duas Vias do Da natureza. Na sua perspectiva, a argumentação monista visa apenas fornecer as condições de compreensão do real, e não descrevê-lo. Por isso mesmo, na sequência da citação de B16, em defesa do princípio da contradição, observa que os filósofos:

“... investigaram a verdade acerca dos entes, mas consideram entes apenas os sensíveis, e nestes em muito inere a natureza do indeterminado e a do ser...” (Met. Г5,1010a2-4).

Como mostrarei adiante, esta cadeia de observações prenuncia todo um programa de pesquisa. Não creio, portanto, que possa contribuir para fazer de Parmênides um físico. Limito-me a aproveitá-la como reforço da interpretação, atrás desenvolvida, da possibilidade de encarar "é" como um pensamento sem referência no real $^{48}$.

III. Ser e pensar: o problema da referência

Comparando as leituras platônica e sofística do argumento da Via da Verdade, é fácil perceber que se inspiram na problematização eleática das relações entre pensamento e ser. Ao identificar pensamento e ser, Parmênides concebe uma faculdade cognitiva superior, à qual chama 'pensamento'. A esse único pensamento viável atribui

\footnotetext{
48 "Ato de pensamento", para J. Solana Dueso, Op. Cit., 48. Contra a interpretação aqui apresentada, recorrendo aos textos citados na seção A dos Fragmente der Vorsokratiker, de Diels-Kranz (acima referidos), o Autor interpreta Parmênides como um físico. Concordo que a delimitação dos domínios da epistemologia e da Física conduz à negação do alcance ontológico da Via da Verdade. Opto, porém, por ler a Via da Opinião como o alargamento da crítica epistemológica ao modo como as "opiniões dos mortais" constroem o mundo mediante o complexo da doxa.
} 
um referente ideal, que denomina "o que é", ou "o ser". Realiza deste modo uma tripla revolução na tradição reflexiva grega:

- a partir da análise do discurso, constitui uma "realidade" supra-sensível à qual atribui identidade, verdade e implicitamente existência;

- introduz uma exigência epistêmica que o conhecimento comum não se acha em condições de satisfazer;

- como consequência destas duas inovações, promove a desvalorizacão do saber dos mortais, que confronta com o argumento desenvolvido no Poema.

É a partir deste ponto que se dividem as águas. Enquanto para Platão todo pensamento se refere ao ser, os sofistas encaram-no como auto-referencial. Quer isto dizer que para eles qualquer pensamento se refere apenas à entidade pensada; não à entidade existente e real que o discurso aparenta designar, que consideram inexistente ou inacessível.

As razões indicadas para mediar um abismo entre pensamento e realidade encontram-nas nos argumentos que apresentam tanto sobre a diversidade de modos como uma mesma entidade é pensada por uma variedade de pensantes, como sobre a possibilidade de nomear entidades inexistentes ou negar a existência de entidades. Em suma, os sofistas defendem que, usando o discurso, o pensamento é incapaz de provar de modo irrefutável, primeiro, a existência de uma realidade exterior, depois, a capacidade de a acessar através dele e, finalmente, de transmitir esse pensamento a outrem $^{49}$.

Através da associação de pensamento e discurso à experiência senso-perceptiva da multiplicidade dos homens comuns, evidenciam aquilo mesmo que a deusa já tinha provado: que o ser se mostra inacessível às opiniões dos mortais. A estratégia que seguem não passa, portanto, pela demonstração da irreferencialidade do discurso, mas sugestão da sua auto-referencialidade, através da acumulação de aporias resultantes na circunscrição do referente do pensamento a si próprio e ao discurso que o exprime.

\footnotetext{
${ }^{49}$ Interpreto a objeção dos sofistas num contexto erístico. Mais do que provar a inacessibilidade do conhecimento à realidade exterior, os argumentos de Górgias e Protágoras visam desconstruir o argumento eleático que desqualifica as "opiniões dos mortais" em nome de uma abordagem formalista do pensamento e da linguagem.
} 
Journal of Ancient Philosophy Vol. III 2009 Issue 2

\section{Platão}

É esta auto-referencialidade do pensamento que Platão nega. Primeiro, prova que há boas razões para aceitar a existência de entidades reguladoras do conhecimento que se achem acima das flutuações das capacidades cognitivas dos indivíduos: as Formas. Demonstra depois a possibilidade de, através do pensamento (ou do "saber": epistêmê) as acessar e comunicar a outros. É para atingir estes objetivos que formula e resolve os problemas apontados nos passos dos diálogos elencados acima.

Deste modo, corresponde à estratégia auto-referencialista dos sofistas com dois movimentos convergentes. Postula uma realidade inteligível, estruturante da alma tanto a do cosmo, quanto a dos mortais -, à qual se aplica a atividade cognitiva. Por outra via, garante o acesso a esta "realidade" pela implementação do modelo cognitivo da reminiscência, suportado pela metodologia dialética de investigação. A estrutura é enquadrado pela moldura mito-poética grega.

Todavia, as concepções eleática e platônica da cognição continuarão reféns da argumentação sofística enquanto a faculdade cognitiva superior e o seu referente ideal se mostrarem incapazes de captar a realidade sensível. Enquanto o referente das Formas permanecer no inteligível, a epistemologia platônica não consegue utilizar a lógica eleática como instrumento de pesquisa da realidade sensível.

Fica, portanto, claro que o problema não é o de como o pensamento ganhou capacidade referencial. Se a própria natureza do pensamento, como faculdade cognitiva, lhe pode impor um referente, não é sobre ele que o confronto se dá, mas sobre a natureza e domínio de aplicação dessa faculdade, ao mesmo tempo.

Será possível, em virtude do argumento eleático, conferir a um pensamento ideal a capacidade de captar uma realidade supra-sensível, identificada pela conjunção dos sentidos do verbo 'ser', "fundidos" na sua unidade semântica; o que significa inseparáveis ${ }^{50}$ ? É aceitável conceder a essa faculdade superior e só a ela a realidade plena que o ser condensa, ignorando o mundo sensível?

\footnotetext{
${ }^{50}$ Nesta medida, não se poderá deixar de lhe reconhecer um sentido existencial, desde que não lhe seja imposto um sentido idêntico àquele que o Sofista platônico lhe conferirá, como predicado distinto, partilhado por todas as coisas que existem.
} 
Journal of Ancient Philosophy Vol. III 2009 Issue 2

Sobra então o não pequeno problema de decidir para que serve essa redefinição do pensar humano, se deixar de fora a captação da realidade visível. Para o resolver há que permitir o trânsito entre o inteligível e o sensível; o que implica fazer uma revisão auto-crítica de concepções da TF, propostas noutros diálogos.

\section{Aristóteles}

Toda esta cadeia de problemas é afastada pelas propostas de Aristóteles nos domínios da Lógica, Filosofia da Linguagem, Epistemologia e Ontologia. Com a tese de que o ser "se diz de muitas maneiras", o Estagirita começa por resolver a tensão que opõe a unidade semântica do verbo 'ser' à ambiguidade das fórmulas que a expressam. Mas só atinge o seu objetivo quando estabelece a distinção entre substância primeira e segunda, sujeito e predicado, potência e ato, matéria e forma, conseguindo desse modo provar a superfluidade da hipótese do inteligível.

Este movimento é suportado por uma estruturação unitária da atividade cognitiva, que a habilita a progredir através da diversidade das faculdades e objetos: da senso-percepção à imaginação e dela à opinião; para chegar não a um, mas a dois "pensamentos", conjuntamente responsáveis pela captação de uma realidade já liberta da cisão que opõe inteligível e sensível.

\section{A identidade revisitada}

É manifesto que todos os programas de pesquisa acima referidos dependem do estatuto da identidade. Na interpretação de Parmênides aqui apresentada, a identidade cunhada pelo uso do pronome to auto - assume um triplo valor. Acima de tudo, é a característica do ser que melhor exprime a sua imobilidade e imutabilidade:

"O mesmo, permanecendo no mesmo, em si mesmo assenta" (B8.29).

O segundo registro da identidade é o do pensamento. Também ele se mostra imutável e idêntico a si próprio na simplicidade da fórmula que propriamente o exprime: "é". Ao invés do que a tradução de noein por "pensamento" sugere (vide supra, n. 9), esta "faculdade" não pode ser caracterizada como um processo, nem se expressa como resultado de um processo. Pelo contrário, para a compreender será 
necessário encará-la como um "estado", do qual a infalibilidade constituirá o sintoma. A teoria platônica das Formas fornece repetidas provas desta interpretação.

Mas o terceiro registro é ainda mais complexo, podendo ser considerado aquele que terá mais funda repercussão em futuras concepções de saber: o da identidade do pensamento com o ser, consignada em B3 e B8.43.

\subsection{Sentido da identidade}

Como se viu atrás, a afirmação da identidade do pensamento com o ser não pode deixar de causar perplexidade ao intérprete atual. Como se poderá admitir a identidade de um real a que supremamente se confere identidade e existência a uma faculdade cognitiva, mesmo considerada superior ${ }^{51}$ ?

A reação imediata do intérprete é supor que a tese de alguma maneira defende um idealismo redutor da realidade ao pensamento. Contra essa possibilidade foram divisadas as duas estratégias atrás referidas: a leitura partitiva de "é" e a importação para B3 e B8.34 da tradução potencial dos infinitos, necessária para entender B2. $2^{52}$.

Contra ambas as leituras, avancei a proposta de encarar "é" como uma exigência do pensamento, expressa pela linguagem, retirando ao ser de Parmênides qualquer ligação à realidade física. Pois não concebo que se possa conferir alcance ontológico a um argumento dedutivo, construído a partir da análise da linguagem ${ }^{53}$.

Defendo que a finalidade destas seções do argumento é apoiar na evidência proporcionada pela linguagem a exploração desse estado cognitivo referido como "o pensamento", contrastando-o com a aplicação que os homens dele fazem no

\footnotetext{
${ }^{51}$ Veja-se a referida crítica de Aristóteles à admissão de uma "faculdade cognitiva superior" da qual não subsistem traços, na refutação da anamnese platônica: Segundos analíticos B19,99b2634. Como sugeri atrás, todo o esforço do Estagirita no Da alma irá no sentido de viabilizar a operação dessa faculdade em conjunto com a estrutura cognitiva comum a todos os animais, e nunca separada dela.

${ }^{52}$ Entre outros, J. Burnet, F. M. Cornford, W. K. C. Guthrie, Kirk \& Raven, L. Tarán. A importação da tradução potencial do infinito, associada à substantivação do pronome to auto visa condensar numa "mesma coisa" ("the same thing") a identidade do que "pode ser pensado e ser".

${ }^{53}$ De resto, argumento que padece da notada falácia de encarar como de re uma predicação de dicto. Apesar de constituir a única alternativa ao não-ser, a possibilidade de ser nunca poderá converter-se em necessidade, como pretende B6.1-2a.
} 
processamento das opiniões a que chegam mediante o exercício das suas faculdades perceptivas.

Produtos dessa crítica do pensar humano são: por um lado, a emergência de uma faculdade cognitiva superior - na realidade, um estado psíquico -, contraposta à sensibilidade; por outro, um argumento que confere ao "ser" os atributos com que o pensamento necessariamente o investe.

Não creio, porém, que se deva investir esse ser com uma dimensão ontológica, expressa numa qualquer realidade física, nem pelo contrário, apostar na idealidade desta. Parmênides parte de um traço comum a todos os poetas - alegar a verdade da mensagem que transmite aos homens -, embora opte por condensar a habitual declaração da origem divina dessa mensagem numa argumentação necessitante. Todavia, a hipótese sobre a qual assenta a argumentação nunca é manifesta no Poema.

Consiste ela na proposta de extração da verdade necessária do pensar do fato de ele ser possível: ["se há um pensar..."], então "há para ele apenas dois caminhos" (B2.2). Só a admissão desta hipótese permite aceitar a rejeição da via negativa (B2.5-8a) sem ter de a remeter para uma "pesquisa" anterior à própria possibilidade da pesquisa (vide $\mathrm{B} 2.2)$.

Pois, não posso aceitar que a justificação da eliminação da via negativa, por não se referir a nada, seja independente da aceitação prévia da realidade do pensar; nem que implique a orientação da capacidade referencial expressa por "é” para o mundo físico. "O ser" deverá ser entendido como a expressão do próprio pensamento, patente na capacidade de afirmar "é" com o discurso ${ }^{54}$.

Consequentemente - e deverá ser esse o sentido da identidade, em B3, B8.34 -, a finalidade programática do argumento do Poema é mostrar a necessidade de submeter não a realidade física, mas o conhecimento aparente que os homens dela terão (B8.3841; 50 ss.;), às exigências postas pelo pensar (Simplício fís. 39,10). É nesta intenção que se apoia toda a mensagem do Poema. Quanto à Via da Opinião, a sua finalidade é denunciar a inconsistência de que parte o exercício da doxa para apontar a via conducente à sua superação (B7.5).

\footnotetext{
54 Vide G. Calogero, "Parmenide", 7. É bem claro que, pelo contrário, a via negativa necessariamente se contradiz, ou ignora, aquilo mesmo a que se aplica.
} 
Esta interpretação mostra não haver razões para onerar Parmênides com a defesa de uma concepção referencial do pensamento. Se "é" exprime o único pensamento "possível” e "dizível” - por contraposição a "o que não é” (B2.7-8a) -, só pode referirse a "o que é".

Nada prova, porém, a associação de "o que é" ao mundo físico. Pois, se, por um lado, a identidade entre pensar e ser é introduzida para negar a possibilidade de pensar o mundo através da experiência sensível; por outro, não parece ser possível que o pensamento se refira a alguma outra realidade "pensável”, exterior a si próprio.

Talvez cause surpresa que esta dupla impossibilidade se verifique também no caso de Platão, que projetivamente defende a capacidade referencial do $\operatorname{saber}^{55}$. Embora o mundo exterior seja processualmente percebido pelo complexo da doxa, enquanto a epistêmê visar as Formas, a infalibilidade deste estado encerra as tarefas da percepção e imaginação na aparência ${ }^{56}$ (Sofista 264a-b; vide Timeu 52a), impedindo-as de ter acesso à realidade inteligível.

A consequência é a omni-presente reafirmação do dualismo. No plano ontológico, as Formas são a referência do saber, mas não podem existir fisicamente, como ocorre com as suas imagens sensíveis. Por essa razão, a existência separada das Formas, exigida no Parmênides 132b-c, dará origem à série de insuperáveis aporias que rematam a primeira parte do diálogo e se consubstanciam nas perguntas que definem o eterno programa da atividade filosófica (135b-c). Por outro lado, no plano epistemológico, não haverá modo de conectar o processo construtivo da doxa à exigência de infalibilidade que caracteriza o estado designado pelo termo epistêmê.

\subsection{Futuro da identidade}

${ }^{55}$ Faltam informações sobre a teoria onto-epistemológica - se a houve - concebida por Antístenes para suportar a sua concepção do "enunciado próprio". Nada menos do que ela seria necessária para impedir o tom depreciatório com que Platão e Aristóteles a ele se referem.

${ }^{56}$ A aporia final do Teeteto (208c ad fin.) está construída sobre incompatibilidade da opinião com o saber. Sobre a oposição de "estado" a "processo" na comparação das faculdades cognitidas, vide José Trindade Santos, "Introdução", Platão, Teeteto, Lisboa 2005, 5-177 (esp. 55-57, 119-123, 162-166). É por esta razão que Aristóteles critica Platão por considerar a imaginação uma mistura de percepção com opinião (Da alma $\Gamma 3$, 4282a4-26). A imaginação não pode consistir na associação de duas faculdades distintas - a senso-percepção e a opinião -, que podem entrar em conflito uma com a outra (como no caso em que o Sol parece medir um pé de comprimento). 
De modo independente da presença da argumentação eleática praticamente na totalidade da obra platônica, a defesa da identidade do pensamento e do ser ocupa nos diálogos uma posição fulcral. Em primeiro lugar, é ela que confere sentido à anamnese e à onto-epistemologia platônica. A estruturação cognitiva da alma, resultante da sua "congenitura" (syngeneia: Mênon 81b) com as Formas, é constitutiva de toda a possibilidade de cognição tanto do inteligível, como do visível que a partir dele se estrutura (Fédon 72-76).

O argumento da República V 476e ad fin. reforça este ponto de vista apontando a insanidade do complexo da doxa. Contra ele, justificada pelo fato de não satisfazer a exigência de identidade, formal e material, do cognoscível, a imutabilidade e perfeição das Formas será apontada como condição e finalidade do saber. A inatingibilidade desse estado psíquico está bem patente na Carta VII 342b-e, 343b-c. Sem "o quinto" modo cognitivo - “o que é em si cognoscível e verdadeiramente é” (342c1) -, não há realidade para conhecer; tal como, sem a sua captação, serão inviáveis todas as tentativas de alcançar o saber.

Embora Aristóteles tenha conseguido superar todas estas dificuldades, a sua rejeição de uma faculdade cognitiva superior às conhecidas levanta-lhe outros problemas. Obriga-o a mostrar que toda a cognição, em última análise, a dos primeiros princípios, resulta do exercício de faculdades reconhecidas e comuns a toda a Humanidade (Segundos analíticos B19).

Com essa opção, dá o passo definitivo, que Platão nunca deu com sucesso, de apontar um complexo e diversificado processo psíquico ao estado que dele resulta; sem o qual, porém, o próprio processo nem sequer seria possível ou teria explicação.

Começa por resolver o problema através da total submissão da atividade cognitiva à exigência de identidade (através da "semelhança"). Proposta no início do I capítulo do Da interpretação (assim como a escrita simboliza a oralidade, os pensamentos são "semelhantes" às coisas: DI 16a6-8), no Da alma B- $\Gamma$, a identidade retorna sistematicamente em cada um dos passos da cadeia ascendente da cognição, da senso-percepção até ao pensamento.

Mas há dois momentos a isolar neste percurso. No Da alma B5, Aristóteles consegue pela primeira vez separar três modos de conhecimento, distinguindo - mas ao 
Journal of Ancient Philosophy Vol. III 2009 Issue 2

mesmo tempo associando - a faculdade, conferida a todos os humanos, e o seu exercício - uma e outro, consideradas como processos -, do estado resultante da captação do universal na natureza ${ }^{57}$.

Por isso, o momento culminante da sua análise é aquele em que consegue ligar o processo ao estado cognitivo. Vemo-lo expresso nas linhas dedicadas à comparação do "pensamento passivo" com o "pensamento produtivo", em Г4-5. Para entender como, bastará traduzir três frases de $\Gamma 5$ :

"Há um pensamento passivo que é tal (toioutos) por chegar a ser todas as coisas e outro que, por produzi-las todas, é como um certo tipo de estado (hôs hexis tis), como (hoion) a luz" (430a15-16);

“... o conhecimento em ato é o mesmo (to auto) que a coisa" (Id., Ibid. 20);

"uma vez separado, só esse, contudo, é precisamente o que é, e esse só é imortal e eterno $^{58}$ (Id., Ibid. 23-24).

Noutro contexto, esta mesma tese, mantendo ainda o vínculo cognitivo, abre já para um domínio teológico:

“O pensamento pensa-se a si mesmo por captação do inteligível: fazendo-se inteligível por contato (thiganôn) e pensando, de modo que pensamento e inteligível são o mesmo" (tauton nous kai noêton: Met. $\Lambda 7,1072 b 19-21)$.

Não causará, portanto, surpresa encontrar transposta esta mesma defesa da identidade, do domínio da cognição, para o da mística contemplativa:

"Se assim é [a contemplação anterior à divisão entre contemplador e possuidor], a contemplação deve ser o mesmo que o contemplado, e o pensamento o mesmo que o inteligível, pois, se não for o mesmo, não será verdade" (Plotino, En. V3.5.22-24).

\footnotetext{
${ }^{57}$ A captação do universal será o estado terminal daquilo que na realidade consiste, não num processo, mas numa sucessão de estados cognitivos associados pela "semelhança": da percepção de sensíveis per se até à captação do universal (sobre o paralelo da percepção com o conhecimento e a dissolução do processo em estados, vide H. Lorenz, "The Assimilation of Sense to Sense Object in Aristotle", OS APh XXXIII, Winter 2007, 179-220).

${ }^{58}$ Tradução de Marcelo Boeri, em curso de publicação. Agradeço ao autor ter-me permitido o acesso ao texto, bem como o apoio prestado no mini-curso sobre o Da alma que levou a cabo na UFPB, em Novembro de 2008.
} 
Journal of Ancient Philosophy Vol. III 2009 Issue 2

Separados dos dois contextos de que provêm, um, evidentemente platônico, o outro, mais profundo, eleático, estes passos parecerão misteriosos. E bastará atentar na longa linhagem das interpretações a que deram origem para o perceber. No entanto, concretizam a suposição, presente em toda a tentativa de conhecimento, para todos clara como um axioma, de que, se há conhecimento, ele não pode deixar de ser idêntico ao conhecido.

O meu primeiro objetivo com este texto foi mostrar que esse axioma tem raízes metafísicas. Na verdade, defendo não só que é com ele que a metafísica começa no Ocidente, como que é por causa dele que continua e continuará viva.

Bibliografia

\section{FONTES:}

Antístenes, Antisthenis fragmenta, collegit Fernanda Decleva Caizzi, Milano 1966

Aristóteles

Aristotelis Opera. Ex recensione I. Bekkeri ed. Academia Regia Borussica. Bd. I-II: Text, III: Lateinische Renaissance Übersetzungen, IV: Scholia, V: Fragmente und H.Bonitz, Index Aristotelicus, Berlin,1831-1870. ND, Berlin, 1960

Fragmenta. Ed. V. Rose, Leipzig, 1886. N.D,Stuttgart, 1967

The Works of Aristotle, translated into English under the editorship of W. D. Ross, IXII, Oxford,1908-1913 (The Complete Works of Aristotle. The Revised Oxford Translation, I-II, Edited by J. Barnes, Princeton, 1984

Categories and De Interpretatione. Transl. with notes by J. L. Ackrill. Oxford, 1974.

Prior and Posterior Analytics. Ed. with introd. and comm. by W. D. Ross. Oxford, 1949.

Aristotle's Physics. A revised text with introduction and commentary by W. D. Ross. Oxford, 1936 (1966).

Physique. Texte établi et traduit par H. Carteron. Paris, 1926 (1961).

Du Ciel . Texte établi et traduit par P. Moraux. Paris, 1965.

Traité du Ciel, suivi du traité Pseudo-Aristotélicien du Monde. Trad. et notes par J. Tricot, Paris, 1949.

De anima. Ed. with introd. and commentary by D.W.Ross, Oxford, 1961.

De l'âme. texte établi et traduit par A. Janone et E. Barbotin. Paris, 1966. 
Journal of Ancient Philosophy Vol. III 2009 Issue 2

Metaphysics, Ed. with introd. and comm. by W. D. Ross, I-II Oxford, 1924 (1966).

Metafísica, Ed. trilingüe de V.Garcia Yebra. Madrid, 1970.

Górgias

Gorgias, Fragmentos, Introducción, traducción y Notas de P. C. T. Zuñiga, Mexico 1980.

Parmênides

Parmênides, Da natureza, Tradução, comentário e notas de José Trindade Santos, S. Paulo 2003.

H. Coxon, The Fragments of Parmenides, Assen 1986.

Platão

Platonis Opera. Ed. I.Burnet. I-V, Oxford, 1900-1907.

Oeuvres complétes, I-XIV, Paris, Les Belles Lettres, 1920-1964.

Plato I-XIII, transl. by W. R. M. Lamb, H. N. Fowler, P. Shorey, R. G. Bury, Loeb Classical Library, London, Cambridge (Mass.) 1914-1935.

Scholia Platonica, ed. by C. Greene, Haverford 1938.

Platão, Teeteto, Lisboa 2005.

Plotino

Plotinus, Enneads I-IX, Loeb Cl. Lib., Cambridge (Mass.), London 1978-1988.

Sexto Empírico

Sextus Empiricus, With an English Translation by R. G. Bury I-IV, Loeb Cl. Lib., Cambrdge (Mass.), London 1986.

Teofrasto

Sobre las sensaciones, Edición, introducción, traducción y notas de J. S. Dueso, Barcelona $2006^{2}$.

\section{LIVROS}

S. Austin, Parmenides. Being, Bounds, and Logic, New Haven and London 1986.

J. Barnes, The Presocratic Philosophers I, London, Henley and Boston, 1979.

J. Burnet, Early Greek Philosophy, London $1930^{4}$.

G. Calogero, "Parmenide", in Studi sull'eleatismo, Firenze 1977 (1ª ed. 1932).

G. Casertano, Parmenide; il metodo, la scienza, l'esperienza, Napoli 1978.

T. Chance, Plato's Euthydemus: Analysis of What Is and Is Not Philosophy, Berkeley and Los Angeles 1992.

T. Chapell, Reading Plato’s Theaetetus, Sankt Augustin 2004.

N.-L. Cordero, Les deux chemins de Parménide, Paris 1984. 
Journal of Ancient Philosophy Vol. III 2009 Issue 2

F. M. Cornford, Plato and Parmenides, London and Henley 1939.

P. Curd, The Legacy of Parmenides: Eleatic Monism and Later Presocratic Thought, Princeton 1998.

N. Denyer, Language, Thought and Falsehood in Ancient Greek Philosophy, London 1991.

Diels, W. Kranz, Die Fragmente der Vorsokratiker, griech. u. deutsch, übers. von $H$. Diels, hrsg. von W. Kranz. I-III, Zürich, Hildesheim 1951-26.

J. S. Dueso, De Logos a Physis, Estudio sobre el Poema de Parmenides, Zaragoza 2006.

G. Giannantoni, Socratis et Socraticorum Reliquiae, I-IV vols., Napoli 1990.

W. K. C. Guthrie, A History of Greek Philosophy II, Cambridge 1965.

P. Horwich, Truth, Oxford 1990.

E. Hussey, The Presocratics, London, 1972.

C. H. Kahn, The Verb 'Be' and its synonyms, The Verb 'Be' in Ancient Greek, Philosophical and grammatical studies edited by W. M. Verhaar, Dordrecht/Boston 1973.

C. H. Kahn, The Verb “BE” in Ancient Greek, "Introduction”, Indianapolis 2003, .

G. S. Kirk, J. E. Raven, Os filósofos pré-socráticos, Lisboa 1979

E. Kühner-Gerth, Ausfürliche Grammatik der griechischen Sprache, 2. Teil, Satzlehre, Hannover-Leipzig 1898-1904.

J. Mansfeld, Die Offenbarung des Parmenides und die menschliche Welt, Assen 1964.

A. P. D. Mourelatos, The Route of Parmenides, New Haven \& London 1970.

J. Palmer, Plato's Reception of Parmenides, Oxford 1999.

W. Quine, Pursuit of Truth, Cambridge 1990.

J. D. Rankin, Sophists, Socratics and Cynics, London and Canberra 1983.

K. Rheinhardt, Parmenides und die Geschichte der griechischen Philosophie, Bonn 1916.

E. C. Souza, Discurso e Ontologia em Platão; uma leitura do Sofista, Ijuí 2009.

R. K. Sprague, Plato's Use of Fallacy: A Study of the Euthydemus and Some Other Dialogues, London 1962.

L. Tarán, Parmenides. A Text with Translation, Commentary, and Critical Essays, Princeton 1965.

\section{COLETÂNEAS}

A. Nehamas, Virtues of Authenticity, Princeton 1999.

A Companion to Ancient Philosophy, M. L. Gill (ed.), Madison, London 2006. 
Journal of Ancient Philosophy Vol. III 2009 Issue 2

Essays in Ancient Greek Philosophy I, J. Anton, L. Kustas (eds.), Albany 1971.

Études sur Parménide, P. Aubenque, D. O’Brien (dirs.), Paris 1987.

Form and Argument in Late Plato, Chr. Gill and M. M. McCabe (eds.), Oxford 1996.

Language, S. Everson (ed.), Cambridge 1994.

Plato I, G. Fine (ed.), Oxford 1999.

Studies in Presocratic Philosophy, R. E. Allen, D. J. Furley (eds.), London 1975.

The Pre-Socratics, A. P. D. Mourelatos (ed.), Garden City, New York 1974.

\section{ARTIGOS:}

L. Brown, "The Verb 'To Be' in Greek Phiosophy": Some Remarks", in S. Everson (ed.), Language, Cambridge 1994, 212-236.

L. Brown, "Being in the Sophist: A Syntactical Enquiry", Plato I, G. Fine (ed.), Oxford 1999 (OSAPh IV, 1986), 455-478.

S. di Camillo, "El problema del logos falso nel Eutidemo y su solución nel Sofista", Hypnos 19, 2007, 1-15.

N.-L. Cordero, “Les deux chemins de Parménide dans les fragments 6 et 7”, Phronesis 24, 1979, 1-32.

P. Curd, "Parmenides and After: Unity and Plurality", A Companion to Ancient Philosophy, M. L. Gill (ed.), Madison, London 2006, 39-42

P. Curd, "Parmenidean Monism", Phronesis 36, 1991.

P. Curd, "Eleatic Arguments, Method in Ancient Philosophy, Oxford 1998

G. Fine, "Conflicting Appearances: Tht. 153d-154b", Form and Argument in Late Plato, Chr. Gill and M. M. McCabe (eds.), Oxford 1996, 105-133.

A. Finkelberg, "Parmenides' Foundation of the Way of Truth", Oxford Studies in Ancient Philosophy VI, Oxford 1988, 39-68.

K. Von Fritz, "Nous, Noein, and their Derivatives in Pre-Socratic Philosophy (excluding Anaxagoras)", The Pre-Socratics, A. P. D. Mourelatos (ed.), Garden City, New York $1974,23-85$.

M. Furth, "Elements of Eleatic Ontology”, The Presocratics, 241-270.

D. H. Graham, "Empedocles and Anaxagoras: Responses to Parmenides", The Cambridge Companion to Early Greek Philosophy, A. A. Long (ed.), Cambridge 1999, 159-180.

C. H. Kahn, "The Greek Verb 'To Be' and the Concept of Being", Foundations of Language 2, 1966, 245-265.

C. H. Kahn, Sobre o Verbo grego Ser e o Conceito de Ser”, M. Iglésias, I. B. Franco (orgs.), Rio de Janeiro (s. d.).

G. Kerferd, "Gorgias on Nature and that which is not", Phronesis 1, 1955, 1-25. 
Journal of Ancient Philosophy Vol. III 2009 Issue 2

W. e M. Kneale, El desarollo de la lógica, Madrid 1980.

F. Leigh, "The Copula and Semantic Continuity in Plato' Sophist", OSAPh XXXIV 2008, 105-122.

J. Malcolm, "Some Cautionary Remarks on the "Is/Teaches" Analogy", OSAPh XXXI 2006, 281-296.

R. D. McKirahan Jr., "Zeno", The Cambridge Companion to Early Greek Philosophy, A. A. Long (ed.), Cambridge 1999, 134-158.

H. Lorenz, "The Assimilation of Sense to Sense Object in Aristotle", Oxford Studies in Ancient Philosophy XXXIII, Winter 2007, 179-220.

M. Miller, "Ambiguity and Transport: Reflections on the Proem to Parmenides' Proem”, Oxford Studies in Ancient Philosophy XXX, 2006, 1-48.

A. Nehamas, "On Parmenides' Three Ways of Inquiry", in Virtues of Authenticity, Princeton 1999, 125-137.

A. Nehamas, "Participation and Predication in Plato's Later Thought", in Virtues of Authenticity, Princeton 1999, 196-223 (esp. 215-218).

D. O'Brien, "Introduction à la lecture de Parménide: les deux voies de l'être et du nonêtre", Études sur Parménide, P. Aubenque (dir.), Paris 1987.

G. Owen, "Eleatic Questions", Studies in Presocratic Philosophy, R. E. Allen, D. J. Furley (eds.), London 1975, 48-81.

R. Ramsey, "Facts and Propositions", reimpr. em Foundations of Mathematics, London 1931, 138-155.

J. T. Santos, “Introdução", Platão, Teeteto, Lisboa 2005, 5-178.

D. Sedley, "Parmenides and Melissus", Cambridge Companion to Early Greek Philosophy, 113-133.

L. Woodbury, "Parmenides on Names", Essays in Ancient Greek Philosophy I, J. Anton, L. Kustas (eds.), Albany 1971, 145-162. 